\title{
ŚCIEŻKI ROZWOJU PRZEDSIĘBIORSTWA - EGZEMPLIFIKACJA ORIENTACJI DZIAŁALNOŚCI PRZEDSIĘBIORSTWA
}

\section{Grzegorz Krzos, Estera Piwoni-Krzeszowska, Jacek Szkólski}

\section{Wprowadzenie}

$\mathbf{R}$ ozwój przedsiębiorstw determinowany jest swoistą historią każdego z nich (Vergne, Durand, 2010). Bez zrozumienia i znajomości przeszłości trudno jest odpowiedzieć na pytanie, skąd biorą się obecne sukcesy lub problemy i co należy zrobić, aby w przyszłości osiągać lepsze rezultaty (Obłój, 2017). Przedsiębiorstwa, dążąc do osiągnięcia pożądanych efektów swojej działalności, podążają różnymi ścieżkami. Jednak aktualne teorie wyjaśniające rozwój przedsiębiorstwa nie omawiają w stopniu satysfakcjonującym continuum jego obrazów (fotografii) - od narodzin do stanu przedsiębiorstwa w badanym czasie. Wypełnienie tej luki wydaje się cenne poznawczo i utylitarnie. W zakresie nauk o zarządzaniu opracowanie konceptualnego wzorca ścieżki rozwoju przedsiębiorstwa może mieć zastosowanie np. w benchmarkingu modeli rozwoju organizacji (w tym ich cyklu życia) oraz diagnozie i ocenie poziomu złożoności organizacji czy wreszcie ocenie dojrzałości organizacji (jako narzędzie uzupełniające opracowane modele dojrzałości) oraz pomiarze dokonań organizacji. Z kolei w wymiarze praktycznym konceptualny wzorzec ścieżki rozwoju przedsiębiorstwa może być użyteczny np. w ocenie przedsiębiorstwa w trakcie „due dilligence” czy identyfikacji dominujących i uzupełniających orientacji jego rozwoju (Krzos, Piwoni-Krzeszowska, 2018). Jednakże podstawę opracowania tego konceptualnego wzorca ścieżki rozwoju stanowi identyfikacja i propozycja pomiaru orientacji działalności przedsiębiorstwa, które pokazują obraz (fotografię) organizacji w danych momentach jej życia.

W tym kontekście celem artykułu jest zidentyfikowanie elementów orientacji opisujących ścieżkę rozwoju przedsiębiorstwa, które będą stanowić podstawę opracowania metody i narzędzi prezentacji tej ścieżki. Artykuł ma charakter empiryczny. Przeprowadzono eksploracyjne, pojedyncze studium przypadku, rozstrzygające, czy założenia o tych orientacjach, poczynione przez autorów publikacji, są słuszne.

\section{Podstawowe tło teoretyczne ścieżek rozwoju przedsiębiorstwa}

$\mathbf{R}$ ozwój przedsiębiorstwa jest różnie postrzegany (Krzos, Piwoni-Krzeszowska, 2018). Studia literatury skłaniają do wnioskowania, że rozwój przedsiębiorstwa jest zachodzącym w czasie procesem występujących w nim jakościowych i ilościowych zmian o charakterze progresywnym, regresywnym lub stagnacji (Krzos, Piwoni-Krzeszowska, 2018) i obejmuje komplementarne zmiany w różnych sferach i obszarach jego funkcjonowania (Adamik, Zakrzewska-Bielawska, 2014).

Eksplikacji rozwoju przedsiębiorstw można poszukiwać w przekroju czterech teorii, a mianowicie: cyklu życia, teleologicznej, dialektycznej oraz ewolucyjnej (Van de Ven, Poole, 1995). Ich studia skłaniają do wnioskowania, że przedsiębiorstwo, działając intencjonalnie, podlega ciągłej ewolucji. Zmiany zachodzące w czasie jego funkcjonowania mają charakter inkrementalny lub przełomowy. Są też rezultatem oddziaływania czasem sprzecznych czynników wewnętrznych i zewnętrznych, które wpływają na różnicowanie i retencję funkcjonowania organizacji. Ważność zmian zaś podlega selekcji (Krzos, Piwoni-Krzeszowska, 2018).

Historia przebiegu zmian w działalności przedsiębiorstwa jest odzwierciedlona w ścieżce jego rozwoju. Badania w tym zakresie, zasługujące na podkreślenie, były podejmowane przez N. Siggelkowa (2001; 2002), ale dotyczą one jedynie egzemplifikacji problematyki rozwoju przedsiębiorstw i próby opracowania typologii ścieżek ich rozwoju. Natomiast nie proponują operacjonalizacji obrazów organizacji i ich zmian w czasie o względnie uniwersalnych walorach. To inklinuje wniosek, że występuje luka badawcza w tym obszarze. Jej wypełnienie wydaje się być ważne, jeśli przyjmie się, że ścieżka rozwoju przedsiębiorstwa, pokazując ewolucję przebiegu i zmian orientacji jego działalności, składa się z wielu obrazów organizacji opisywanych przy użyciu wybranych przez przedsiębiorstwo wymiarów tych orientacji. Powstaje jednak pytanie, jakie orientacje działalności przedsiębiorstwa powinny być brane pod uwagę, żeby wyczerpująco opisać jego obraz. Studia literatury (Stabryła, 1995; Bratnicki, Austen, 2005; Flamholtz, Hua, 2003; Siggelkow, 2002) skłaniają do postawienia pytań: a) czy może niezamknięty, ale wystarczający do opisania funkcjonowania przedsiębiorstwa zbiór tych orientacji zawiera się w orientacjach na: produkty, procesy, funkcje, projekty, innowacje i technologię, ekspansję geograficzną, sieciowość, b) jak zoperacjonalizować pomiar tych orientacji? Znalezienie odpowiedzi na te pytania wymaga jednak przeprowadzenia badań empirycznych. 


\section{Metoda badawcza}

$\mathrm{K}$ rytyczna analiza literatury pozwoliła na przyjęcie założenia badawczego, że może niezamknięty, ale wystarczający do opisania funkcjonowania przedsiębiorstwa zbiór orientacji działalności przedsiębiorstwa, stanowiących podstawę opisu ścieżki jego rozwoju, zawiera się w orientacjach na: produkty, procesy, funkcje, projekty, innowacje i technologię, ekspansję geograficzną, sieciowość. Poza tym otwarte pozostaje dalej pytanie, jak zoperacjonalizować pomiar tych orientacji. Przyjęto założenie, że:

- wymiarami orientacji produktowej mogą być: liczba produktów, liczba modyfikacji produktów, orientacja struktury organizacyjnej na produkt,

- wymiarami orientacji na procesy mogą być: liczba procesów, liczba modyfikacji procesów, orientacja struktury organizacyjnej na proces,

- wymiarami orientacji na funkcje mogą być: liczba funkcji, liczba modyfikacji funkcji, orientacja struktury organizacyjnej na funkcje,

- wymiarami orientacji na projekty mogą być: liczba projektów, liczba modyfikacji projektów, orientacja struktury organizacyjnej na projekty,

- wymiarami orientacji na technologię mogą być: liczba zastosowanych innowacyjnych rozwiązań technologicznych, stopień dojrzałości technologicznej, liczba patentów, zgłoszeń patentowych oraz know-how,

- wymiarami orientacji na ekspansję geograficzną mogą być: liczba rynków regionalnych, liczba rynków zagranicznych,

- wymiarami orientacji na sieciowość mogą być: liczba podmiotów, częstotliwość relacji, charakter relacji, miejsce w sieci.

Niedostatki wyjaśnień teoretycznych, przejawiające się $\mathrm{w}$ nieprecyzyjnym określeniu ścieżki rozwoju przedsiębiorstwa, a nawet obszaru badawczego, ze względu na brak ustaleń operacjonalizacji jej opisu, determinują wybór metody case study.

Postawiono następujące pytania badawcze:

1. Czy przyjęte założenia o rodzajach i elementach składowych orientacji prezentujących ścieżkę rozwoju przedsiębiorstwa są słuszne i czy nie należy w ogóle zmienić kierunku dalszych badań?

2. Jak w praktyce postrzegane są te orientacje i jakie wymiary je opisują?

Badanie jest zatem eksploracyjnym, pojedynczym studium przypadku, rozstrzygającym, czy poczynione założenia o orientacjach działalności przedsiębiorstwa, stanowiących podstawę opisu ścieżki jego rozwoju, są słuszne, czy może trzeba zmienić ich zbiór, jak również odkrywczym, jak opisać te orientacje. Badanie ma charakter pilotażowy i stanowi wstęp do rozpoczęcia studium wielokrotnego.

Obiektem badawczym w niniejszym artykule jest Avenir Medical Poland Sp. z o.o., która przeszła ścieżkę rozwoju od startupu do średniego przedsiębiorstwa. Badanie dotyczy okresu, w którym AMP był startupem, czyli przedsiębiorstwem prowadzącym innowacyjną działalność w okresie do 3 lat od momentu jego założenia. Główną przyczyną wyboru do badania startupu jest specyfika tego typu organizacji, a w szczególności ich endo- i egzogeniczny potencjał rozwojowy oraz jego determinanty $\mathrm{w}$ najtrudniejszym okresie $\mathrm{z}$ perspektywy teorii cyklu życia organizacji. Funkcjonowanie startupu cechuje duża zmienność, wpływ wielu zjawisk wewnętrznych i zewnętrznych na jego działalność oraz wyniki. Przykładowo $20 \%$ startupów wspartych w ostatnich latach milionami z Krajowego Funduszu Kapitałowego już nie prowadzi działalności (Duszczyk 2018). Dlaczego tak jest? Czy można było tego uniknąć? Są to przykładowe pytania, na które można uzyskać odpowiedzi, znając trajektorię rozwoju przedsiębiorstwa i jej determinanty.

Źródła danych stanowi wywiad pogłębiony ze współzałożycielem Medical Avenir Polska Sp. z o.o. oraz jego dokumentacja.

Sformułowano następujące pytania badawcze:

a) jakie orientacje działalności przedsiębiorstwa powinny być brane pod uwagę, żeby wyczerpująco opisać obraz jego ścieżki rozwoju?

b) czy może niezamknięty, ale wystarczający do opisania funkcjonowania przedsiębiorstwa zbiór tych orientacji zawiera się w orientacjach na: produkty, procesy, funkcje, projekty, technologię, ekspansję geograficzną, sieciowość? c) jak zoperacjonalizować pomiar tych orientacji?

W badaniu wykorzystano następujące metody analizy danych: odwoływanie się do założeń teoretycznych oraz technikę dopasowania wzorców.

Wiodącą słabością zastosowanej strategii badawczej jest generalizacja analityczna. Zwiększenie prawdopodobieństwa jej słuszności wymaga przeprowadzenia studiów przypadku o charakterze iteratywnym w celu rozwinięcia koncepcji ścieżki rozwoju przedsiębiorstwa do dalszych badań i wygenerowania hipotezy o jej modelowym przebiegu.

\section{Obrazy ścieżki rozwoju organizacji na przykładzie Avenir Medical Poland Sp. z o.o.}

A venir Medical Poland Sp. z o.o. (dawniej Avenir Medical S.C.) powstała w styczniu 2005 roku jako startup. Produkty Spółki są sprzedawane za pośrednictwem wyspecjalizowanej detalicznej sieć sprzedaży „Twoje Soczewki” (B2C). Założycielami Spółki są absolwenci Uniwersytetu Ekonomicznego we Wrocławiu: Jacek Szkólski i Paweł Grędysa.

AMP działa na rynku polskim w obszarze detalicznej sprzedaży produktów medycznych dopuszczonych do obrotu pozaaptecznego. Głównym przedmiotem działalności jest sprzedaż następujących produktów i usług optycznych/okulistycznych: soczewki kontaktowe, produkty do pielęgnacji soczewek kontaktowych, okulary słoneczne, okulary korekcyjne, badania okulistyczne. Grupę docelową spółki AMP stanowią: kobiety, wykształcone lub uczące się, mieszkające w mieście. Podstawowe dane o liczbie pracowników i wskaźniku EBITA w latach 2005-2008 są zamieszczone w tabeli 1 jako elementy charakteryzujące wielkość przedsiębiorstwa i ekonomiczną skalę działalności startupu. 
Tabela 1. Liczba pracowników i wskaźnik EBITA AMP Sp. z o.o. w pierwszych 4 latach od założenia

\begin{tabular}{|c|c|c|c|c|}
\hline & 2005 & 2006 & 2007 & 2008 \\
\hline $\begin{array}{c}\text { Liczba } \\
\text { Pracowników }\end{array}$ & 2 & 5 & 14 & 26 \\
\hline EBITA (zt) & 105000 & 150000 & 278000 & 454000 \\
\hline
\end{tabular}

Źródło: dokumentacja AMP Sp. z o.o.

Rosnąca liczba pracowników i wzrost wskaźnika EBITA świadczy o progresywnym rozwoju Spółki.

Wywiad przeprowadzony $\mathrm{z}$ respondentem wykazał, że $\mathrm{w}$ jego opinii stosownymi wymiarami do opisu orientacji produktowej AMP Sp. z o.o. są:

- liczba produktów,

- liczba kategorii produktów,

- liczba modyfikacji produktu,

- liczba stanowisk związanych z zarządzaniem produktem, np. menedżer produktu.

Dane dotyczące orientacji produktowej w przedsiębiorstwie AMP Sp. z o.o., uzyskane podczas badania, przedstawiono na rysunku 1.

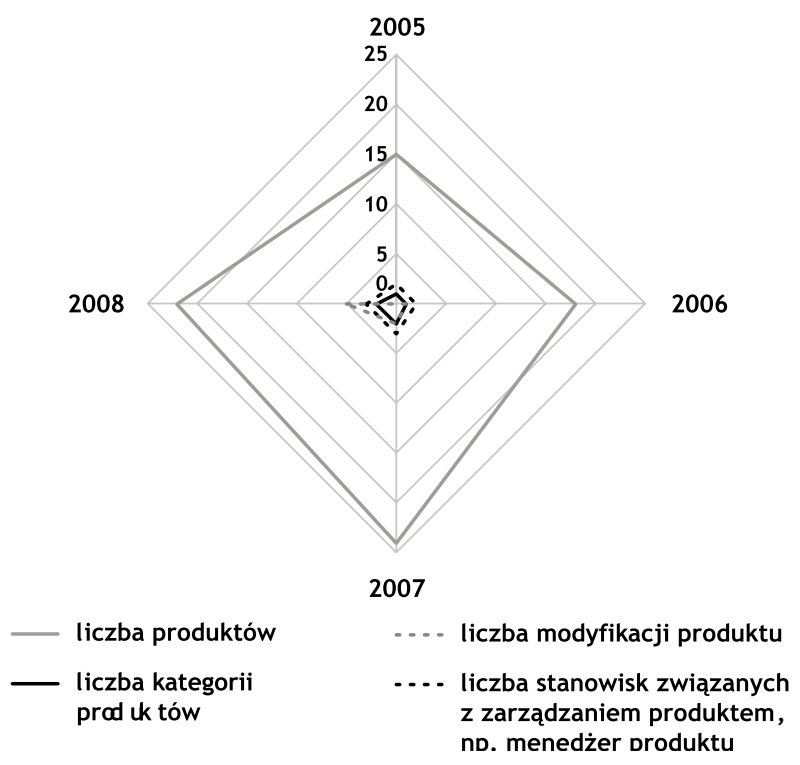

Rys. 1. Orientacja produktowa

Źródto: opracowanie wtasne

Analiza wyników dotyczących orientacji produktowej AMP Sp. z o.o. na przestrzeni pierwszych 4 lat działalności wskazuje, że Spółka w pierwszych latach rozwoju koncentrowała się na rozszerzeniu asortymentu i wprowadzeniu dodatkowych kategorii produktowych.

Wywiad przeprowadzony $\mathrm{z}$ respondentem wykazał natomiast, że w jego opinii stosownymi wymiarami do opisu orientacji geograficznej AMP Sp. z o.o. są:

- liczba jednostek (oddział/spółka „córka”) będących własnością spółki „matki” i działających zagranicą,

- liczba jednostek pomocniczych działających w kraju na rzecz zagranicznych oddziałów lub spółek „córek”,

- liczba krajów, w których dostępny jest produkt,

- liczba jednostek prowadzących sprzedaż w kraju macierzystym,
- liczba regionów, w których prowadzona jest sprzedaż w kraju macierzystym.

Rysunek 2 prezentuje orientację geograficzną Spółki w latach 2005-2008. Można z niego wywnioskować, że AMP Sp. z o.o. była zogniskowana na silny rozwój organiczny w Polsce, rozszerzając swoją działalność na coraz więcej regionów w kraju macierzystym. Poza obszarem zainteresowania Spółki były jeszcze rynki zagraniczne.

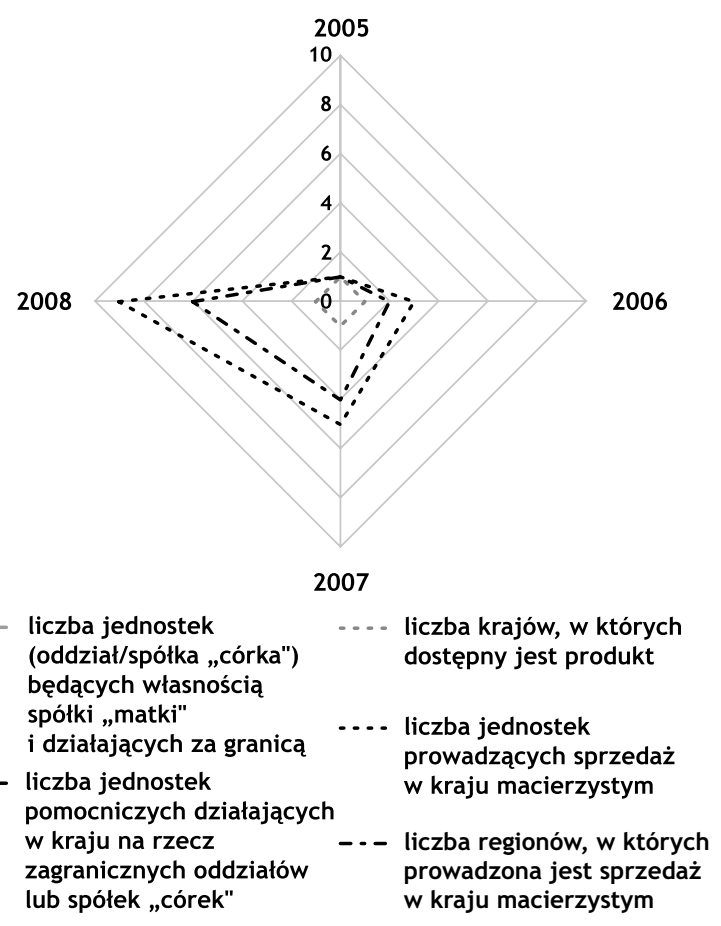

Rys. 2. Orientacja geograficzna

Źródło: opracowanie wtasne

Wywiad przeprowadzony z respondentem wykazał też, że w jego opinii stosownymi wymiarami do opisu orientacji projektowej AMP Sp. z o.o. są:

- liczba projektów strategicznych,

- liczba projektów operacyjnych,

- liczba stanowisk uczestniczących w projekcie,

- liczba narzędzi stosowanych w procesie zarządzania projektem.

Na rysunku 3 zaprezentowana jest orientacja projektowa AMP Sp. z o.o. Można zaobserwoać, że w początkowej fazie rozwoju omawiane przedsiebiorstwo jest organizacją zoorientowaną na projekty zarówno o charakterze operacyjnym, jak i strategicznym.

Wywiad przeprowadzony z respondentem ujawnił, że jego zdaniem orientacja technologiczna powinna być rozszerzona o wymiar innowacyjny i powinna nosić nazwę orientacja technologiczno-innowacyjna. W opinii respondenta stosownymi wymiarami do opisu orientacji technologiczno-innowacyjnej AMP Sp. z o.o. są:

- liczba wdrożonych innowacji w danym roku,

- liczba zaplanowanych innowacji do zastosowania w danym roku,

- liczba patentów, zgłoszeń patentowych, znaków towarowych w danym roku. 


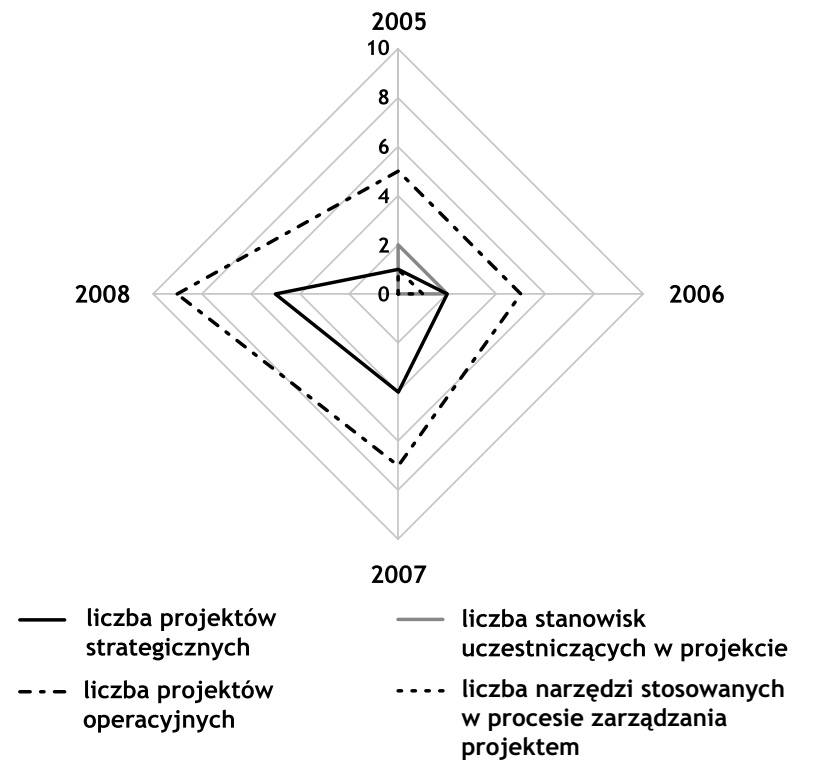

Rys. 3. Orientacja projektowa

Źródto: opracowanie własne

Na rysunku 4 zaprezentowano orientację Spółki w obszarze technologiczno-innowacyjnym. W ramach tej orientacji wyróżniono zaplanowane innowacje do zastosowania i innowacje, które udało się wdrożyć. Liczba patentów i zarejestrowanych znaków towarowych jest również ważnym elementem stanowiącym o unikalności danego konceptu biznesowego. Najwięcej zgłoszeń patentowych i znaków towarowych Spółka uzyskała w drugim roku działalności (w 2006 r.). W kolejnych latach liczba ta jest niższa, ale utrzymuje się na tym samym poziomie, co może świadczyć o stablinym rozwoju działalności badawczo-rozwojowej.

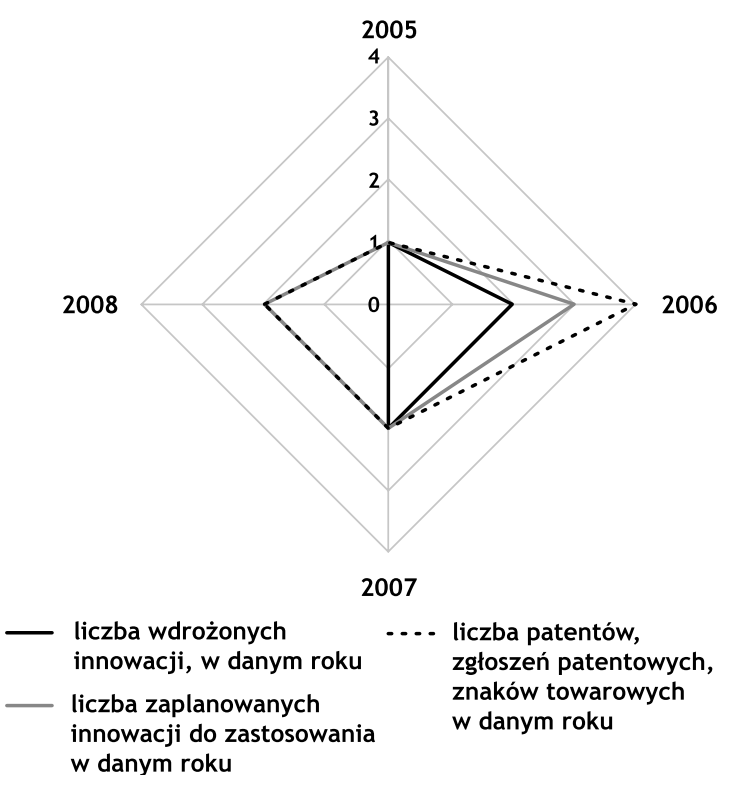

Rys. 4. Orientacja technologiczna/innowacyjna Źródto: opracowanie wtasne

W opinii respondenta stosownymi wymiarami do opisu orientacji funkcjonalnej AMP Sp. z o.o. są:

- liczba funkcji (pionów) w schemacie organizacyjnym,

- liczba modyfikacji zmieniających funkcjonalny charakter struktury organizacyjnej.
Orientacja funkcjonalna Spółki przedstawiona została na rysunku 5. Analizując uzyskane wyniki w tym obszarze, warto porównać je $\mathrm{z}$ wynikami $\mathrm{z}$ badania orientacji projektowej. Porównanie tych wyników jednoznacznie wskazuje, że AMP Sp. z o.o. wraz ze swoim rozwojem przechodziła $z$ orientacji projektowej na funkcjonalną.

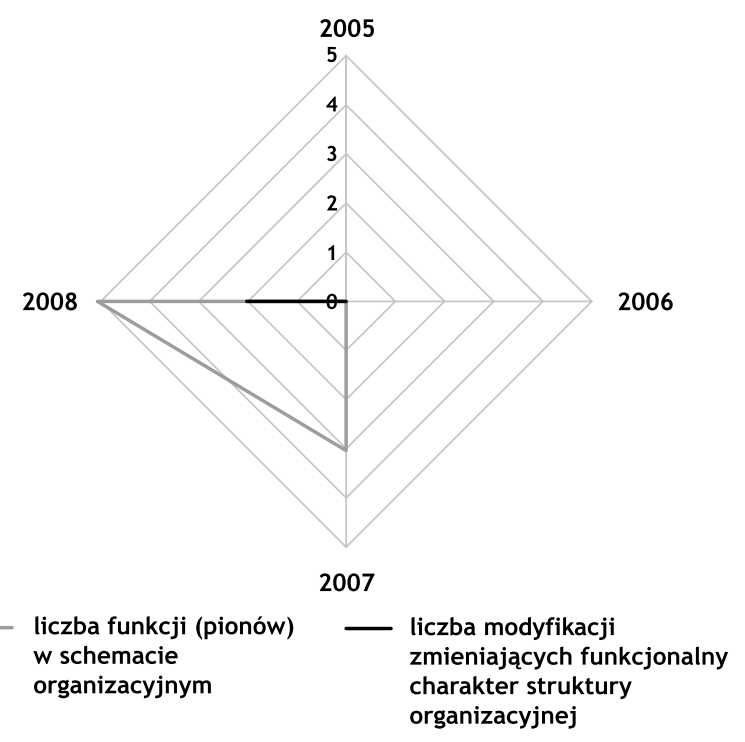

Rys. 5. Orientacja funkcjonalna

Źródto: opracowanie wtasne

W opinii respondenta stosownymi wymiarami do opisu orientacji procesowej AMP Sp. z o.o. są:

- liczba stanowisk charakterystycznych i występujących w zarządzaniu procesem, np. menedżer procesu,

- liczba procesów operacyjnych, np. proces księgowania, proces rekrutacji,

- liczba procesów strategicznych (kluczowych), np. proces obsługi i realizacji zamówienia klienta.

Rysunek 6 przedstawia orientację procesową Spółki. Uwidacznia on zdecydowane rozgraniczenie procesów operacyjnych i strategicznych oraz przewagę tych pierwszych. Świadczy to może, iż dominantą orientacji procesowej są procesy operacyjne, które doskonalą wycinkowe obszary działalności przedsiębiorstwa zamiast kompleksowych. Takie podejście jest charakterystyczne dla pierwszych etapów rozwoju organizacji i wczesnych poziomów dojrzałości przedsiębiorstwa. Dodatkowo wyszczególniona została liczba stanowisk o charakterze procesowym dla wszystkich procesów łącznie (operacyjnych i strategicznych), która z roku na rok rośnie, co świadczyć może o coraz większej złożoności i dojrzałości procesowej organizacji.

Wywiad przeprowadzony $\mathrm{z}$ respondentem wykazał również, że w jego opinii stosownymi wymiarami do opisu orientacji sieciowej AMP Sp. z o.o. są:

- liczba instytucji otoczenia biznesu,

- liczba dostawców,

- liczba klientów ( ${ }^{*}$ liczba klientów 1 na wykresie $=1000$ w rzeczywistości),

- liczba użytkowników (czyli niepłacących za produkty/ usługi klientów),

- liczba relacji krótkoterminowych,

- liczba relacji długookresowych. 


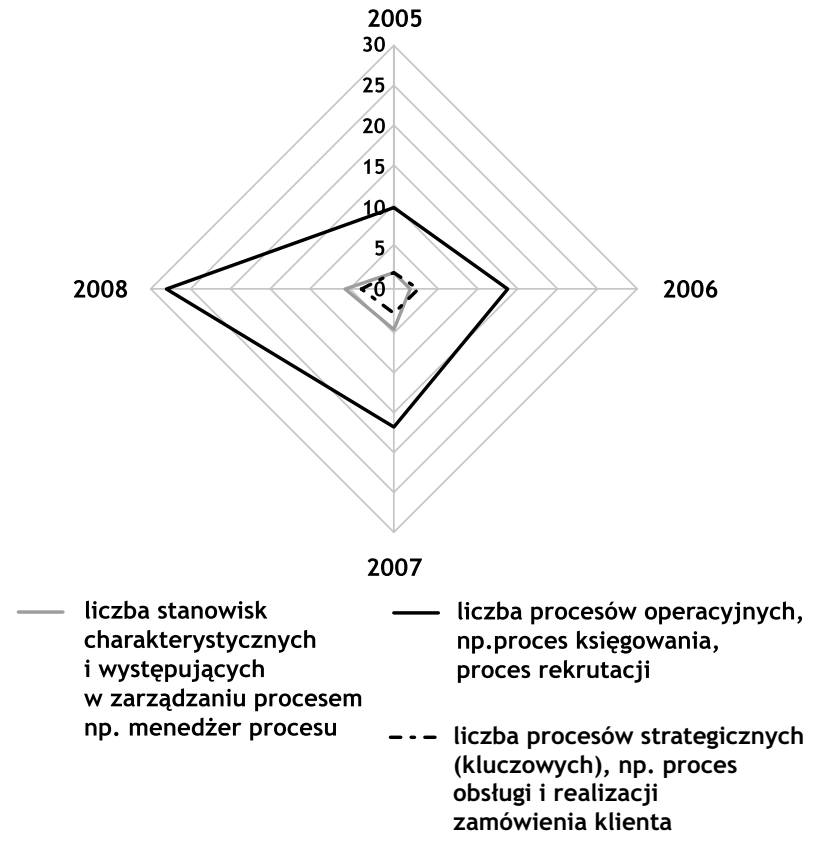

Rys. 6. Orientacja procesowa

Źródło: opracowanie własne

$\mathrm{Na}$ rysunku 7 zaprezentowano orientację sieciową Spółki. Wykres ten pokazuje wszystkie relacje B2B i B2C na przestrzeni pierwszych 4 lat dzielności. Spółka sprzedaje produkty w modelu B2C, więc liczba klientów jest zdecydowanie większa niż podmiotów współpracujących $\mathrm{z}$ przedsiębiorstwem. $\mathrm{Na}$ przestrzeni lat obserwuje się wzrost liczby relacji ze wszystkimi podmiotami i ich utrzymywanie w dłuższej perspektywie. Świadczy to o rosnącym usieciowieniu działalności Spółki. Zauważalna jest również dominacja relacji krótkoterminowych nad długookresowymi, co wskazuje na bardziej transakcyjny charakter relacji.

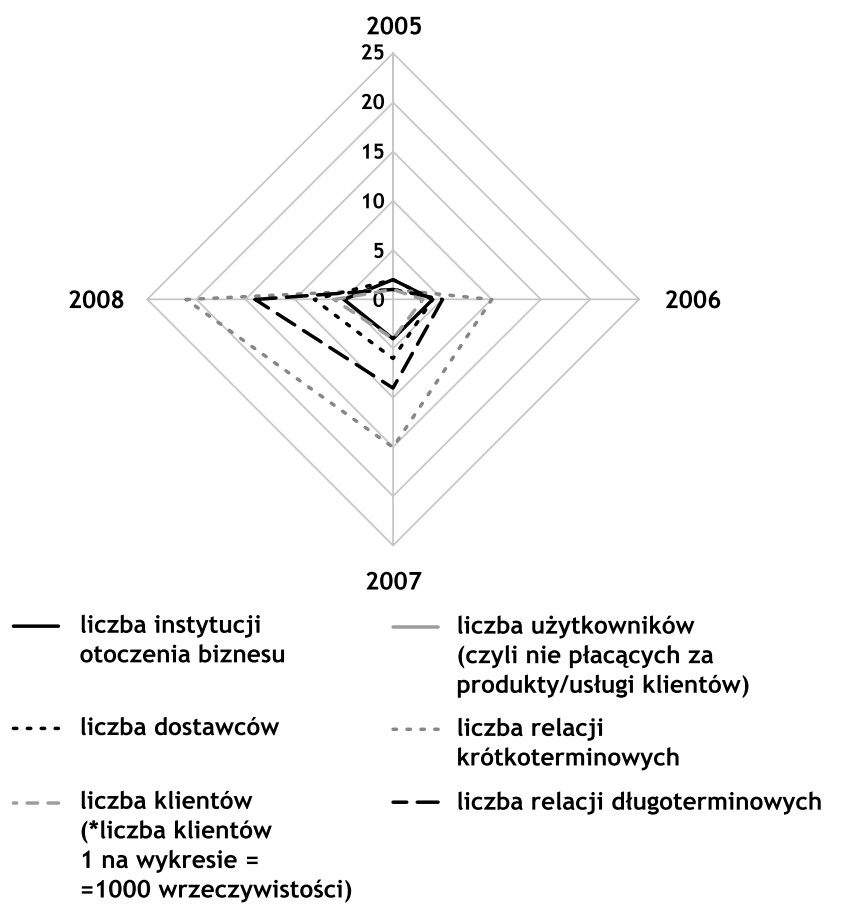

Rys. 7. Orientacja sieciowa (relacyjna)

Źródto: opracowanie własne

\section{Wyniki badań}

D rzeprowadzone badanie empiryczne potwierdza, że założony zestaw orientacji działalności przedsiębiorstwa opisujący ścieżkę jego rozwoju jest właściwy i można kontynuować badania w tym względzie.

Badanie pokazało, że rozwój AMP Sp. z o.o. obejmuje komplementarne zmiany w różnych sferach i obszarach jego funkcjonowania, co pozostaje w zgodzie z poglądem A. Adamik i A. Zakrzewskiej-Bielawskiej (2014, s. 25).

Należy jednak podkreślić, że badanie to ma charakter pilotażowy, a więc można wnioskować, że orientacjami działalności przedsiębiorstwa, które powinny być brane pod uwagę, żeby opisać obraz ścieżki jego rozwoju, są:

- orientacja na produkty, na co zwraca również uwagę A. Stabryła (1995, s. 7) oraz E. Flamholtz i W. Hua (2003, s. 224),

- orientacja na procesy, funkcje, projekty, o których w kontekście rozwoju przedsiębiorstwa pośrednio wspominają A. Stabryła (1995, s. 7) oraz E. Flamholtz i W. Hua (2003, s. 224),

- orientacja na technologię i innowacje, oraz istotność technologicznego wymiaru rozwoju, co podkreśla też A. Stabryła (1995, s. 7),

- orientacja na ekspansję geograficzną, co znajduje swoje odzwierciedlenie też w opinii E. Flamholtz i W. Hua (2003, s. 224),

- orientacja na sieciowość, co pozostaje w zgodzie z poglądem E. Stańczyk-Hugiet (2013, s. 121), że nie można abstrahować od relacji międzyorganizacyjnych, które ewoluując determinują adaptację do zmieniających się potrzeb zasobowych.

Niemniej generalizacja analityczna tego wniosku wymaga przeprowadzenia dalszego wielokrotnego studium przypadku. Na tym etapie badań można jedynie sądzić, że zestaw tych orientacji jest wystarczający, ale nie jest zamknięty.

Wyniki badań wskazują również, że postrzeganie wymiarów świadczących o poszczególnych orientacjach przedsiębiorstwa przez respondenta nie jest tożsame z przyjętymi założeniami. Wskazuje to na konieczność przeprowadzenia dalszych, pogłębionych badań w tym obszarze i skłania do zastanowienia się, czy występuje powszechny zestaw wymiarów opisujących poszczególne orientacje, czy jest on może determinowany specyfiką funkcjonowania przedsiębiorstwa, np. działalnością o charakterze startupowym, wielkością przedsiębiorstwa czy branżą. To inklinuje pogląd, że dalszym badaniem o charakterze wielokrotnego studium przypadku powinny być objęte przedsiębiorstwa o różnej specyfice funkcjonowania. Zatem pytanie, jak opisać orientacje działalności przedsiębiorstwa obrazujące ścieżkę jego rozwoju, pozostaje dalej otwarte. W kolejnych badaniach należy podczas wywiadów pogłębionych sprawdzić, czy wymiarami:

- orientacji na produkty są: liczba produktów, liczba kategorii produktów, liczba modyfikacji produktów, orientacja struktury organizacyjnej na produkt,

- orientacji na procesy są: liczba procesów operacyjnych i strategicznych, liczba modyfikacji procesów, orientacja struktury organizacyjnej na proces, 
- orientacji na funkcje są: liczba funkcji, liczba modyfikacji funkcji, orientacja struktury organizacyjnej na funkcje,

- orientacji na projekty są: liczba projektów strategicznych i operacyjnych, liczba modyfikacji projektów, orientacja struktury organizacyjnej na projekty,

- orientacji na technologię i innowacje są: liczba zastosowanych innowacyjnych rozwiązań technologicznych, liczba planowanych innowacji w danym roku, stopień dojrzałości technologicznej, liczba patentów, zgłoszeń patentowych oraz know-how,

- orientacji na ekspansję geograficzną są: liczba rynków regionalnych, liczba rynków zagranicznych, liczba jednostek pomocniczych krajowych i zagranicznych,

- orientacji na sieciowość są: liczba podmiotów, częstotliwość relacji, trwałość relacji, miejsce $\mathrm{w}$ sieci oraz zidentyfikować ewentualnie pozostałe wymiary tych orientacji.

Otwarta kwestia operacjonalizacji orientacji działalności przedsiębiorstwa obrazujących ścieżkę jego rozwoju inspiruje do postawienia pytania, czy jest możliwe zbudowanie zagregowanego miernika każdej z tych orientacji, który wskazywałby na ich intensywność i zachodzące $\mathrm{w}$ nich zmiany. Brak odpowiedzi na to pytanie dodatkowo pobudza do prowadzenia pogłębionych badań w tym obszarze.

\section{Podsumowanie}

$\mathbf{S}$ tudia literatury wykazują, że występuje w niej luka badawcza dotycząca ścieżek rozwoju organizacji. Przeprowadzone badanie $\mathrm{z}$ wykorzystaniem metody pojedynczego studium przypadku potwierdziło, że wystarczający, lecz niezamknięty zestaw orientacji działalności przedsiębiorstwa opisujących ścieżkę jego rozwoju obejmuje orientacje na produkty, procesy, funkcje, projekty, technologię i innowacje, ekspansję geograficzną, sieciowość. Otwarta pozostaje dalej kwestia operacjonalizacji tych orientacji. Wypełnienie tej luki wymaga przeprowadzenia dalszych jakościowych badań empirycznych. Uzyskane z tych badań wyniki powinny podlegać dalszej weryfikacji ilościowej, która udzieliłaby również odpowiedzi na pytanie, czy możliwe jest zaproponowanie uniwersalnego zestawu orientacji działalności przedsiębiorstwa, które mogłyby służyć prezentacji i omówieniu ścieżek rozwoju organizacji, Dopiero po przeprowadzeniu tych badań możliwe byłoby przystąpienie do badań longitudinalnych, które umożliwiłyby prezentację ścieżek rozwoju przedsiębiorstw i zidentyfikowanie ewentualnych prawidłowości $\mathrm{w}$ ich przebiegu w badanej populacji. Omówione zaś $\mathrm{w}$ tym artykule badanie empiryczne wskazuje kierunki przyszłych badań nad ścieżkami rozwoju przedsiębiorstw w warstwie teoriopoznawczej, metodycznej i empirycznej.

\author{
dr hab. Grzegorz Krzos \\ Uniwersytet Ekonomiczny we Wrocławiu \\ Wydział Zarządzania, Informatyki i Finansów \\ ORCID: 0000-0001-8423-934X \\ e-mail: grzegorz.krzos@ue.wroc.pl
}

\section{dr hab. Estera Piwoni-Krzeszowska Uniwersytet Ekonomiczny we Wrocławiu Wydział Zarządzania, Informatyki i Finansów ORCID: 0000-0001-6900-768X e-mail: estera.piwoni-krzeszowska@ue.wroc.pl}

\author{
mgr Jacek Szkólski \\ Avenir Medical Poland Sp. z o.o. \\ e-mail: jacek@szkolski.com
}

\section{Bibliografia}

[1] Adamik A., Zakrzewska-Bielawska A. (2014), Istota rozwoju przedsiębiorstw high-tech, [w:] A. Zakrzewska-Bielawska (red.), Koopetycja w rozwoju przedsiębiorstw high-tech. Determinanty i dynamika, Wydawnictwo Placet, Warszawa, s. 10-62.

[2] Bratnicki M., Austen A. (2005), Strategia ogniw pośrednich, czyli przedsiębiorcze uczenie się przez porażkę, [w:] R. Krupski (red.), Zarządzanie strategiczne. Strategie małych firm, Prace Naukowe Wałbrzyskiej Wyższej Szkoły Zarządzania i Przedsiębiorczości, Wałbrzych, s. 233-250.

[3] Duszczyk M. (2018), Inwestycje w startupy na razie bez efektów, „Rzeczpospolita. Biznes”, https://www.rp.pl/ Biznes/310029923-Inwestycje-w-startupy-na-razie-bez-efektow.html, data dostępu: 3.10.2018 r.

[4] Flamholtz E., Hua W. (2003), Searching for Competitive Advantage in the Black Box, „European Management Journal", Vol. 21, No. 2, pp. 222-236.

[5] Krzos G., Piwoni-Krzeszowska E. (2018), Propozycja konceptualnego wzorca ścieżki rozwoju przedsiębiorstwa - założenia teoretyczne, „Przedsiębiorczość i Zarządzanie”, t. 19, z. 6, cz. 2 Konkurencyjność współczesnych przedsiębiorstw - modele, koncepcje i uwarunkowania, s. 181-194.

[6] Obłój K. (2017), Praktyka strategii firmy. Jak zarządzać przeszłościa, radzić sobie $z$ teraźniejszościa $i$ tworzyć przyszłość, Wydawnictwo Poltext, Warszawa.

[7] Siggelkow N. (2001), Change in the Presence of Fit: The Rise, the Fall, and the Renaissance of Liz Claibor$n e$, "Academy of Management Journal”, Vol. 44, No. 4, pp. $838-857$.

[8] Siggelkow N. (2002), Evolution toward Fit, „Administrative Science Quarterly”, Vol. 47, pp. 125-159.

[9] Stabryła A. (1995), Zarządzanie rozwojem firmy, Księgarnia Akademicka, Kraków.

[10] Stańczyk-Hugiet E. (2013), Dynamika strategiczna w ujęciu ewolucyjnym, Wydawnictwo Uniwersytetu Ekonomicznego we Wrocławiu, Wrocław.

[11] Van de Ven A., Poole M. (1995), Explaining Developmental and Change in Organizations, „Academy of Management Review", Vol. 20, No. 3, pp. 510-540.

[12] Vergne J., Durand R. (2010), The Missing Link between the Theory and Empirics of Path Dependence: Conceptual Clarification, Testability Issue, and Methodological Implications, „Journal of Management Studies”, Vol. 47, No. 4, pp. 736-759. 
Enterprise Development Paths Exemplification of Company's Orientation

\section{Summary}

The aim of the paper is to identify elements of orientations describing the path of enterprise development. The considerations constitute the basis for developing the method and tools for measuring the orientation of company's activities, which show the picture of the organisation at a given moment and whose changes present its development path over time. The paper presents the research that was carried out on the basis of an exploratory, single case study, which answers the question whether the assumptions about these orientations made by the authors of the publication were correct. The study conducted with the use of the single case study method has confirmed that a sufficient, but not closed, set of company's activities orientations describing the path of its development includes categories like products, processes, functions, projects, technology and innovation, geographic expansion, and inter-organisational networks. The operationalization of the company's activities orientation showing the path of its development requires further research in the form of a multiple cross case study.

\section{Keywords}

organisational development, development path, organisational orientation 